\title{
EXPERIMENTAL INFECTION OF HUMAN VOLUNTEERS WITH THE U-VIRUS-A STRAIN OF ECHO VIRUS TYPE 11
}

\author{
By F. E. BUCKLAND, M. L. BYNOE, L. PHILIPSON* \\ AND D. A. J. TYRRELL \\ The Common Cold Research Unit, Salisbury, Wilts
}

(With 5 Figures in the Text)

\section{INTRODUCTION}

In the course of a study of non-diphtheritic croup in children in the University Hospital of Uppsala, Philipson and Wesslén (1958) isolated a virus from the throat and faeces of patients suffering from this condition. A similar virus was also isolated from children in a day nursery who had symptoms of a mild respiratory infection, but it was not found in children attending hospital with non-infective conditions.

The virus was given the provisional name of U-virus. It was unlike any of the recognized respiratory viruses yet its presence in the patients appeared to be closely associated with an infection of a respiratory nature. In many ways it resembled one of the $\mathrm{ECHO}$ viruses but it was not neutralized by a pool of antisera against ECHO viruses 1-14 (Philipson \& Wesslén, 1958) and seemed to be much larger-it failed to pass a membrane filter with a labelled porosity of $150 \mathrm{~m} \mu$ in preliminary tests (Philipson, 1958a). Philipson (1958b) was able to transmit the infection to some adult mental patients by spraying cultures of the virus on to the mucous membrane of the nose and throat.

Further experimental work was obviously indicated; one of us (L.P.) who had been intimately concerned with the original study of this virus sent a culture to the Common Cold Research Unit in the hope that its nature might be more clearly defined and that further transmission experiments might be done employing the highly co-operative volunteers available to this unit. It was thought that the results obtained by this means might well be more reliable than those furnished by mental patients.

Virus

MATERIALS AND METHODS

The cultures used were derived from the original strains of the U-virus isolated in 1956-57 by Philipson \& Wesslén (1958). Two types of tissue cultures were used for inoculum in the transmission experiments :

(a) A pool of virus passed three times in human embryo-lung tissue culture with bovine anniotic fluid as the maintenance medium. (This was some of the same batch of material that was used by Philipson (1958b).) With either human

* A visiting worker from the University Hospital, Uppsala, Sweden. 
embryo-lung or monkey kidney tissue cultures maintained in medium 199 the virus titre was found to be $10^{6.5} \mathrm{TCD}_{50} / \mathrm{ml}$.

(b) Virus culture after eleven serial passages in monkey kidney tissue maintained in medium 199; the titre was $10^{7.5} \mathrm{TCD}_{50} / \mathrm{ml}$. This virus culture appeared to affect monkey kidney cells rather more quickly than the original human embryo-lung culture.

The identity of both cultures was checked by virus neutralization tests. Culture (a) was used in the first series of human transmission experiments and culture $(b)$ in the second; the dose administered in both series was the same-10 $0^{5} \mathrm{TCD}_{50}$ in $1 \mathrm{ml}$.

\section{Tissue cultures for virus isolation}

In most instances these were trypsin-dispersed rhesus monkey kidney or human embryo-lung cells, but occasionally plasma clot cultures of lung were employed. Tissue cultures were maintained in $2 \%$ calf serum and $0.25 \%$ lactalbumin hydrolysate in Hanks' balanced salt solution containing $0 \cdot 1 \%$ sodium bicarbonate. At times monkey kidney cells were maintained in medium 199; cultures maintained in this medium appeared to be more sensitive to the virus than those employing the other maintenance medium.

\section{Serological tests}

Haemagglutination inhibition tests were done in plastic depression plates using human O-group red cells. The standard technique (Expert Committee on Influenza, 1953) was followed except that the serum-virus mixtures were allowed to react for $1 \mathrm{hr}$. at $37^{\circ} \mathrm{C}$. before the red cells were added.

Virus titrations and neutralization tests closely followed the techniques used with poliomyelitis virus. Mixtures of fourfold dilutions of the sera and 100-1000 TCD of virus were held at $37^{\circ} \mathrm{C}$. for $4 \mathrm{hr}$. after which volumes of $0.1 \mathrm{ml}$. of each mixture were transferred to two separate tissue cultures. The results were read after 4 days' incubation and the titres expressed as $50 \%$ neutralization end-points.

Complement-fixation tests were done in accordance with the technique described by Balducci, Zaiman \& Tyrrell (1956). The antigen was undiluted virus tissue culture fluid which had received a single treatment with fluorocarbon (Arcton 63) in accordance with the procedure of Pereira \& Valentine (1958).

\section{Estimation of virus size}

The standard filtration technique with Gradocol membrane filters of known porosity was supplemented by a sedimentation method similar to that described by Melnick, Rhian, Warren \& Breese (1951). The virus was sedimented in a sucrose density gradient in the angle head of a Spinco model L-ultracentrifuge, but we used haemagglutination titrations to give us an estimate of the position of the sedimentation boundary. 


\section{Human volunteer subjects}

Volunteers, drawn from all parts of the United Kingdom, were housed at the Common Cold Research Unit for the 10-day period of each trial. They comprised twenty males and nineteen females in age groups ranging from 18 to 44 years and were used as test and control subjects in the transmission experiments.

\section{Transmission experiments and clinical studies}

In the original transmission experiments of Philipson (1958b) patients in a mental hospital received the virus as a throat spray, but in ours the dose of virus$10^{5} \mathrm{TCD}_{50}$ in $1 \mathrm{ml}$.-was instilled as nasal drops. The clinical observations and the system of collecting specimens were in accordance with the procedures described by Tyrrell \& Bynoe (1958). Virus recovered from any volunteer, whether from throat or faecal cultures, was identified and typed by haemagglutination inhibition and neutralization tests with specific rabbit antiserum. In studying the antibody response to these induced infections a fourfold or greater rise in antibody titre was regarded as significant.

\section{RESULTS}

Properties and nature of the $U$-virus

With the exception of the estimation of the size of the virus and its antigenic relationship to other known viruses our findings were in agreement with those of Philipson (1958a).

\section{Size of $U$-virus}

We found that the virus passed Gradocol filters of porosities 53 and $51 \mathrm{~m} \mu$ but was retained by those with porosity of $39 \mathrm{~m} \mu$ and less, as shown in Fig. 1. According to Black (1958) the best estimate of the diameter size from these figures would be $28 \mathrm{~m} \mu$.

In two sedimentation experiments the sedimentation constant $\left(\mathrm{S}_{20}\right)$ was estimated at 113 and 105 Svedberg Units, respectively. Assuming the particles to be spherical in shape and to have a density of $1 \cdot 3$, these results would correspond to a particle size of about $26 \mathrm{~m} \mu$.

The measurements by the two methods are therefore in close accord. All Coxsackie and ECHO viruses (with the exception of Type 10 ECHO) studied by filtration technique were found to have a particle diameter size of this order (see Benyesh, Pollard, Opton, Black, Bellamy \& Melnick, 1958; Tyrrell, Clarke, Heath $\&$ Curran, with Beswick \& Wolman, 1958).

\section{Antigenic relationship to other viruses}

We had been personally informed by Dr L. Rosen, National Institutes of Health, Bethesda, Maryland, that he had found the U-virus to be antigenically related to ECHO virus Type 11 and the results of our neutralization tests (see Table 1) confirmed by haemagglutination inhibition agreed with his; more exhaustive results 
will be reported elsewhere (Philipson \& Rosen, 1959). It was therefore concluded that the U-virus was a member of the ECHO group and closely related to Type 11 .

\section{Transmission experiments}

Preliminary trials were carried out on two of the scientific staff of this laboratory and on two of our volunteers. Up to $10^{5} \mathrm{TCD}_{50}$ of a strain of the virus, passaged twenty-two times in monkey kidney tissue, was inoculated; no symptoms were observed in any of the subjects but the virus was recovered from throat swabs or faeces of three of these four.

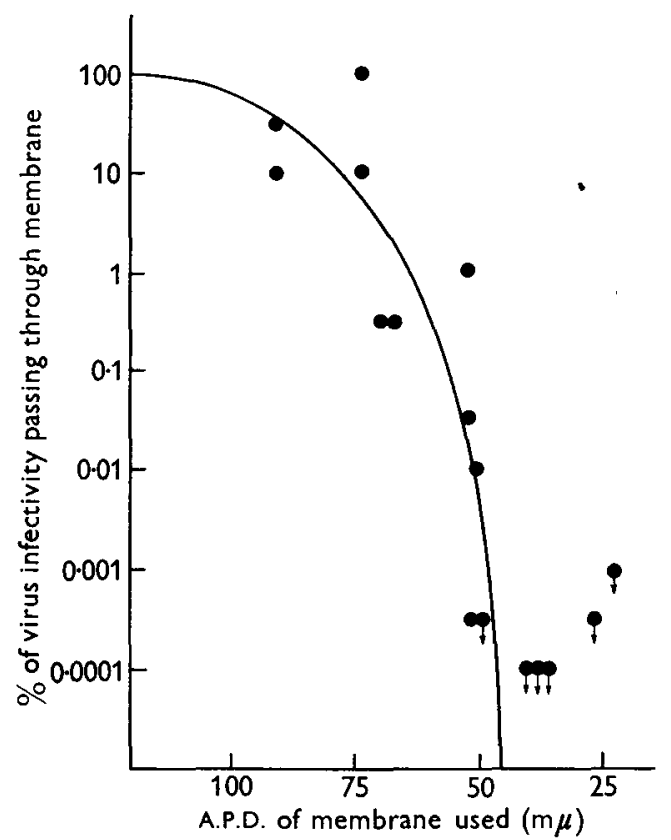

Fig. 1. Reduction in titre of virus after passage through collodion membrane filters. Points with arrows indicate experiments in which no virus was found in the filtrate.

Table 1. Confirmation that ' $U$ ' virus is similar antigenically to ECHO virus Type 11

\begin{tabular}{|c|c|c|}
\hline \multirow[b]{3}{*}{ Virus used } & \multicolumn{2}{|c|}{$\begin{array}{l}\text { Neutralizing antibody titre of } \\
\text { serum prepared against }\end{array}$} \\
\hline & ECHO virus & \\
\hline & Туре 11 & 'U' virus \\
\hline $\begin{array}{l}\text { ECHO Type } 11 \\
\text { (prototype) }\end{array}$ & 512 & 64 \\
\hline U-virus & 128 & 2048 \\
\hline
\end{tabular}

The trials proper were done in two series. The first comprised nine test and eleven control subjects, while the second series comprised eight test and seven control subjects.

In the first series, the test subjects received $1 \mathrm{ml}$. of virus culture fluid, containing $10^{5} \mathrm{TCD}_{50}$ from the third tissue-culture passage of human embryo-lung 
culture maintained in bovine amniotic fluid while the controls received the culture fluid without the virus. Eight of the test subjects developed a mild but definite illness 1-3 days after inoculation; in four of these there was abdominal pain, three of whom also had distension with diarrhoea. Additional signs and symptoms were malaise and sore throat in two, fever in the third and headache in the fourth. Of the remaining four, one had fever with headache, another fever with aching pains in the legs, the third a slight sore throat while the fourth had a 4-day urticaria

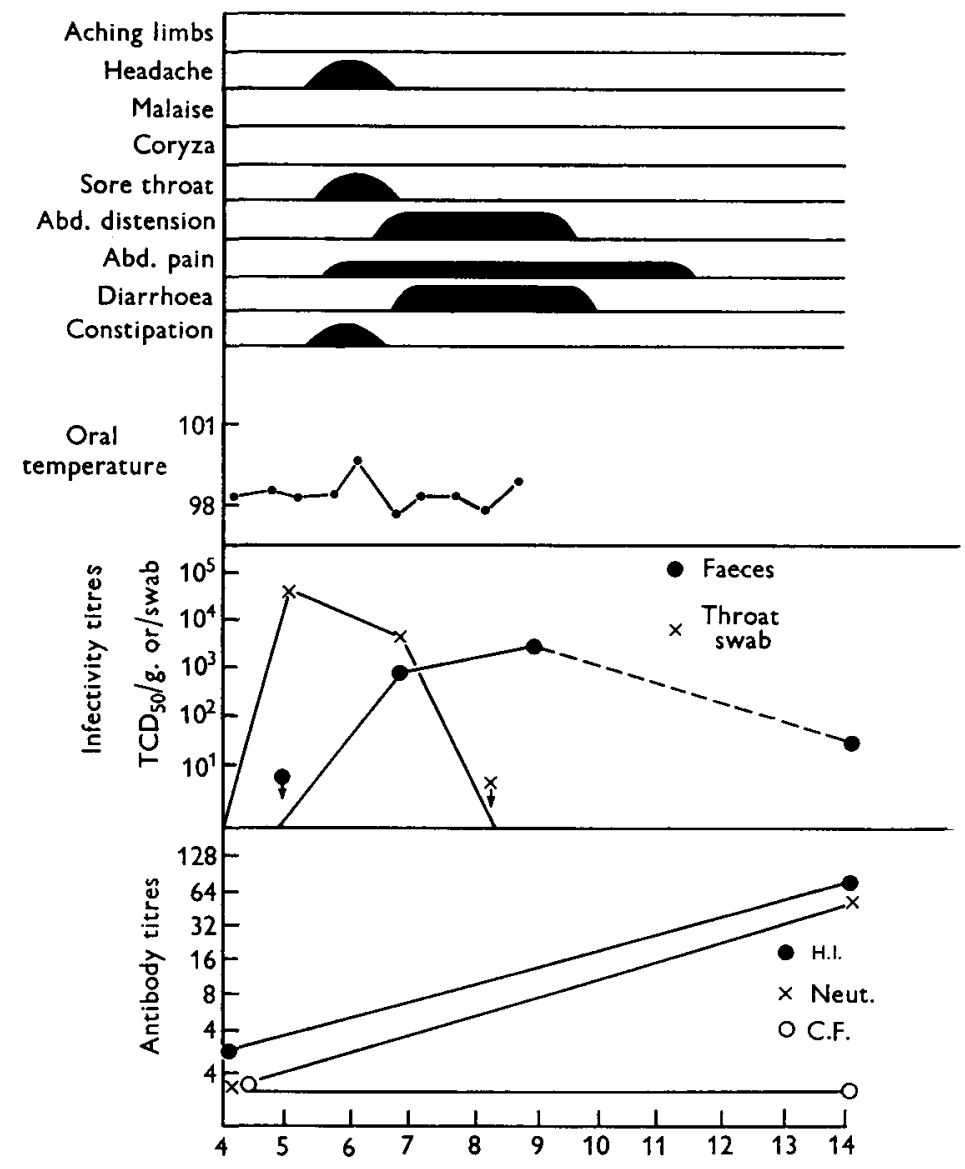

Fig. 2. Clinical and laboratory data on a volunteer from trial 1 who developed a mild illness. The virus was given on day 4. The black areas are intended to show. the time of occurrence and the approximate intensity of the symptoms and signs.

which may, however, have been unconnected with the inoculation (Figs. 2, 3). Of the eleven controls nine were completely symptomless, one had a mild illness with some abdominal pain and the remaining one had a slight fever which had been noted before the inoculation and was not regarded as significant. It was concluded that the virus produced an illness but the clinical picture was that of a mild intestinal upset without any important respiratory symptoms or signs.

The results are consolidated in the upper part of Table 2, which shows that all the test subjects were infected and that virus was recovered from the throats of all 
but one and from the stools of the whole nine. The time of the appearance of the virus corresponded well with the occurrence, when any developed, of the clinical symptoms.

In the second series the inoculum consisted of the culture fluid from the eleventh passage of the virus in monkey kidney tissue culture maintained in medium 199. The dose of virus administered was as previously, $10^{5} \mathrm{TCD}_{50}$ in $1 \mathrm{ml}$. volume. The controls received monkey kidney tissue culture fluid without virus. None of the

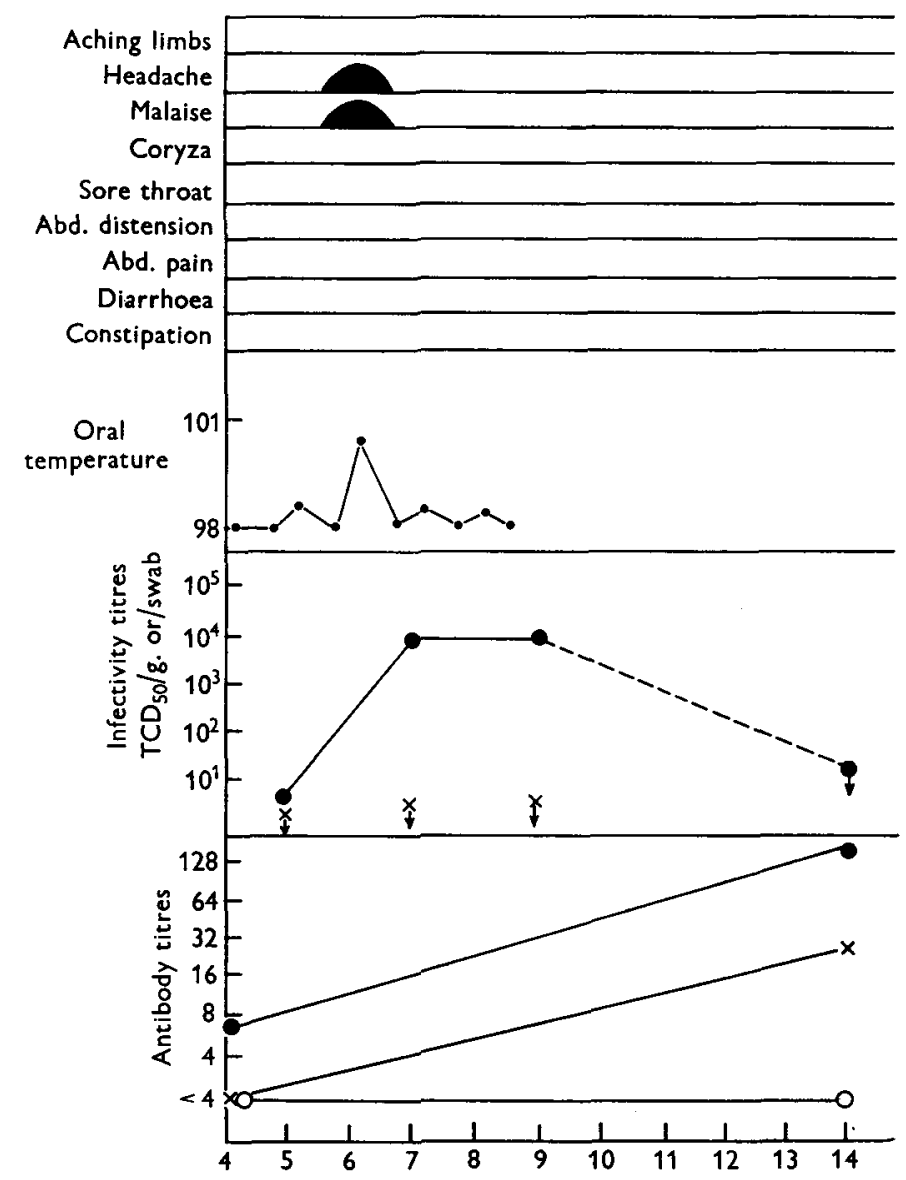

Fig. 3. A chart like Fig. 2. A milder illness. No virus was found in the throat.

Explanation of symbols as in Fig. 2.

test subjects in this series had any definite illness although two had a mild $24 \mathrm{hr}$. pyrexia, and one of these together with a third had a slightly sore throat with some nasal symptoms. Two of the controls were similarly affected, but the remaining five were symptomless. The lower half of Table 2 shows that all the test subjects were also infected, but that the virus recoveries from throat and faecal specimens were less frequent than in the first series of trials. No specimen was recorded as negative until it had been cultured at least twice-usually in both human embryolung and monkey kidney cells-without showing evidence of virus growth. One from the first series and two from the second were still excreting virus two weeks 


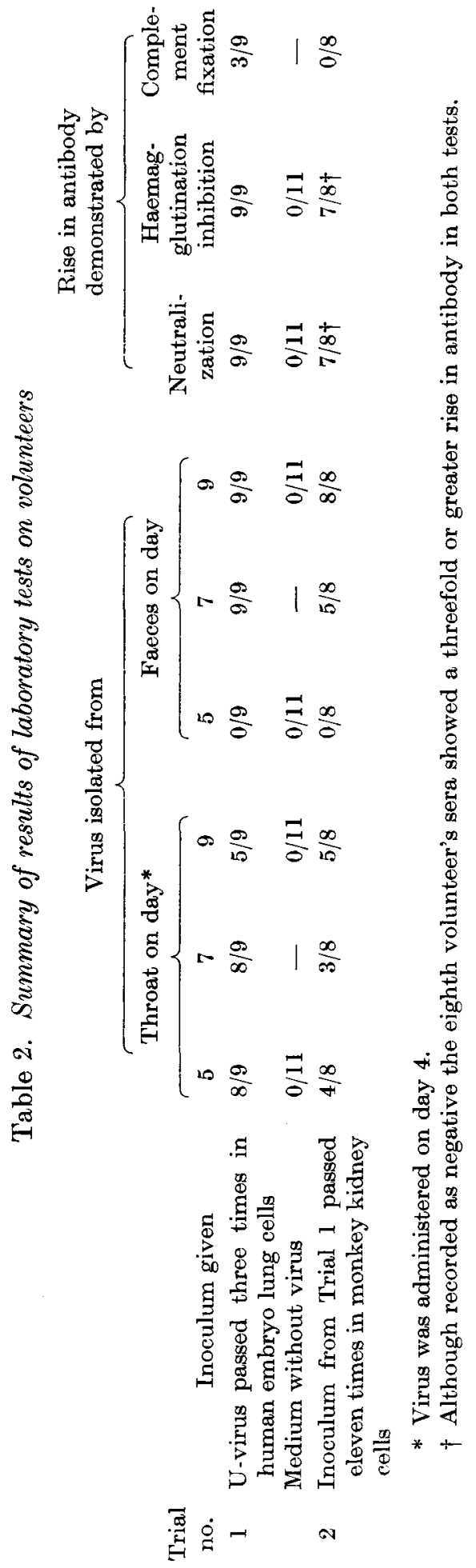


after inoculation. Two consecutive positive specimens from some of the volunteers were available for virus titrations; the geometric mean titre of eight throat swabs of four test subjects in the first series was $10^{2 \cdot 8}$ and of four in the second series was 101.9. The mean titre of eight faecal specimens of four test subjects in the first series was $10^{3 \cdot 9}$ and of four in the second series was $10^{3 \cdot 1}$. The differences found were shown to be statistically significant by the $t$ test $(P<0 \cdot 01)$. It would therefore seem that the excretion of virus after infection with the monkey kidney tissue cultures was at a lower rate than that following infection with the human embryo-lung cultures.

\section{Antibody response to infection}

The paired sera collected from the test subjects in both series and the controls in the first series were examined for haemagglutination inhibition and neutralization antibodies. The test sera were also examined for complement-fixation antibodies.

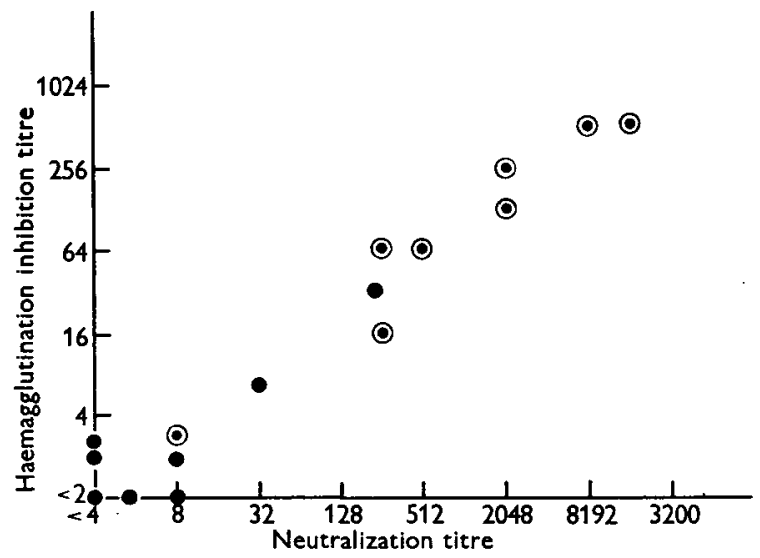

Fig. 4. Neutralizing and haemagglutination-inhibiting antibody titres of sera from volunteers in trial 2. Each point represents one serum. - serum collected before infection; $\odot$ serum collected 2 weeks after infection.

The geometric mean haemagglutination inhibition titres rose from $4 \cdot 4$ to 120 in the first series and $2 \cdot 6$ to 80 in the second series. The mean neutralization titres rose from 1.4 to 134 and from 5.2 to 779 , respectively, in the two series. This indicates, when the two series are combined, that the experimental infection induced an average antibody rise of about 30 -fold as judged by haemagglutination inhibition or about 100 -fold as judged by neutralization. The correlation between the results of the two tests suggests that they probably were both measuring the same antibody. Fig. 4 displays in a graphical form the results of the parallel tests with the sera from the subjects in the second series of experiments; these support that view. The titres correspond well over the whole range and, except for two sera in which the haemagglutination inhibition titre was less than 4 , there was no suggestion that the tests were measuring any inhibitory substance other than neutralizing antibody.

The results of the complement-fixation test, which are also set out in Table 2, do not offer information of much value. 
Sera collected from individuals of different age-groups in the Sheffield area for investigation of influenza in 1955 were kindly made available to us. The method of collection was that employed the year before and reported by Davenport, Hennessy, Stuart-Harris \& Francis (1955).

The results of haemagglutination inhibition tests (Fig. 5) suggested that the population of this country had been exposed to an antigen similar to, or related to, the U-virus and that this exposure occurred in the first few years of life. The tendency for the antibody levels to be high among the older age-groups would support the view that exposure continues into later life. Sera from individuals aged 18-45, bled in 1957-58, showed haemagglutination inhibition with the U-virus at titres of 4-96 in 39/51 such sera tested individually.

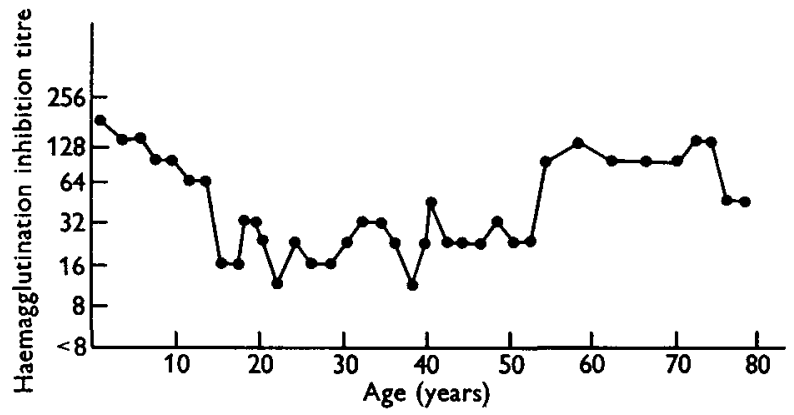

Fig. 5. Haemagglutination-inhibiting antibody titre in pools of human sers collected in England.

\section{DISCUSSION}

In comparing the clinical picture of the Swedish experimental infections (Philipson, $1958 b$ ) with that obtained in our transmission experiments, the outstanding difference appears to be that whereas the Swedish subjects developed a mild upper respiratory condition we were unable to observe any respiratory involvement in our test subjects, only a very slight generalized disturbance of well-being or a mild gastro-intestinal illness. The same pool of virus employed by Philipson in his original trial was used in the experiments reported here although there were differences in dosage and method of administration.

In the Swedish series mental patients were perforce used-a disadvantage since it is well known that the subjective information supplied by volunteers is most important in assessing experimental respiratory infection.

The epidemiological evidence of Philipson \& Wesslén (1958) strongly suggested a direct relationship between the clinical condition and the presence of the U-virus in the children affected, but whether it was in fact the causative agent or a concomitant of a true respiratory unidentified virus, it is not possible to say. Tissue culture of the virus may have modified its effect on the tissue of the respiratory tract just as egg-passage can attenuate the influenza virus (Isaacs, Negroni \& Tyrrell, 1957). It must be admitted, however, that the transmission experiments did not properly imitate the original condition; the experimental subjects were all adults, whereas the original sufferers were young children. 
In accepting the U-virus as a member of the ECHO group and recording it as the first strain of the group to be experimentally transmitted to man, it is of interest to note that the experimental infection is similar to that of natural alimentary infections with other enteroviruses. The significant attenuation of the virus by eleven passages through monkey kidney tissue cultures without loss of antigenicity finds a parallel seen with some strains of poliovirus, where rapid serial passage in monkey kidney tissue culture involves loss of neurotropism, but the immunogenic properties remain (Sabin, Hennessen \& Winsser, 1954). If ever it were thought desirable to immunize against infections with members of the ECHO group it would seem that vaccines prepared from live attenuated strains would be feasible.

\section{SUMMARY}

Re-examination of the U-virus of Philipson \& Wesslén has shown it to be a typical ECHO virus closely related to Type 11 of this group. Ultrafiltration and ultracentrifugation techniques indicate that the virus particle has a diameter of about $27 \mathrm{~m} \mu$ and serological studies confirm its antigenic relationship to the ECHO group.

The virus has been successfully transmitted via the nasal route to volunteer adult subjects. All of them became infected but the clinical picture showed no more than a very mild gastro-intestinal illness or a slight disturbance of the general well-being.

Passage in monkey kidney cells appeared to attenuate significantly when compared with short-term passage in human embryo-lung culture, and this seemed to affect the isolation rate from subjects so infected.

The virus is highly immunogenic. Antibodies to the U-virus have been found in normal persons residing in Great Britain.

We wish to thank the volunteers for their willing co-operation and Miss J. B. Macdonald for help with the clinical observations. Dr A. D. Macrae supplied the ECHO Type 11 prototype virus and immune serum and Prof. C. H. Stuart-Harris supplied the pooled human sera. The Director, Microbiological Research Establishment, Porton, afforded the use of the ultracentrifuge. Monkey kidneys were supplied by the M.R.C. polio vaccine control laboratories. Mr M. C. Brebner and Miss P. K. Pearce assisted with the laboratory work.

\section{REFERENCES}

Balducci, D., Zamman, E. \& Trraeil, D. A. J. (1956). Brit. J. exp. Path. 37, 205.

Benyesh, M., Pollard, E. C., Opton, E. M., Black, F. L., Bellamy, W. D. \& Melnick, J. L. (1958). Virology, 5, 256.

Black, F. L. (1958). Virology, 5, 391.

Davenport, F. M., Hennessy, A. V., Stuart-Harris, C. H. \& Francis, T. JR. (1955). Lancet, ii, 469.

Expert Commitiee on Influenza-First Report (1953). World Hlth Org. Techn. Rep. Ser. 64, W. H. O. Geneva.

Isaacs, A., Negront, G. \& Tyrkell, D. A. J. (1957). Lancet, ii, 886. 
Melnick, J. L., Rhian, M., Warren, J. \& Breese, S. S. (1951). J. Immunol. 67, 151.

Pereira, H. G. \& Valentine, R. C. (1958). J. Gen. Microbiol. 19, 178.

Philipson, L. (1958a). Arch. ges. Virusforsch. 8, 192.

Philirson, L. (1958b). Arch. ges. Virusforsch. 8, 318.

Phitipson, L. \& Rosen, L. (1959). Arch. ges. Virusforsch. 9, 25.

Philipson, L. \& Wesslén, T. (1958). Arch. ges. Virusforsch. 8, 77.

Sabin, A. B., Hennessen, W. A. \& Winsser, J. (1954). J. exp. Med. 99, 551.

TyrRell, D. A. J. \& Bynoe, M. L. (1958). Lancet, ii, 931.

Tyrrell, D. A. J., Clarke, S. K. R., Heath, R. B. \& Curran, R. C., with Beswick, T. S. L. \& Wolman, L. (1958). Brit. J. exp. Path. 39, 178.

(MS. received for publication 4. II. 59) 